\title{
POSTOPERATIVE CHANGES IN SERUM CYTOKINES PROFILE AND NITRIC OXIDE LEVELS IN PATIENTS WITH CYSTIC ECHINOCOCCOSIS
}

\author{
REFIK M.*, MEHMET N.** \& DURMAZ R.*
}

\section{Summary:}

The aim of the present study was to examine serum cytokines and nitric oxide (NO) levels in patients with cystic echinococcosis (CE). 28 patients with CE were studied and all underwent surgery. Serum levels of tumour necrosis factor-alpha (TNF- $\alpha$ ), interleukin IL$1 \beta$, receptor of soluble IL-2R (sIL-2R), IL-6, IL-8, nitrate/nitrite, and C-reactive protein (CRP) were determined before and after induction of treatment. Data were compared with those obtained from 28 healthy volunteers. IL-6 was elevated in all CE patients (100\%). IL-8 was increased in $11 / 28(39.3 \%)$. Increased levels of IL-2R and TNF- $\alpha$ were found in a limited number of them particularly those showing cysts in the central area of the liver 15/28, 6/28). IL-1 $\beta$ level was not elevated in any patient except in secondary severe CE. CRP and nitrate/nitrite levels were also increased. A positive correlation between CRP and IL-6 $\mathrm{l} r=0.74$; $p<0.001$ ) was found confirming the link between inflammation due to CE and activation of monocytes. All patients completely recovered and the levels of the studied parameters reverted to normal levels except one patient in whom severe recurrent disease occurred two years after the first operation. These results suggest that there are different immunoregulatory events and cytokines response during CE and may be in part related to slight monocytosis and in part to Th2 activation. IL-6, NO and CRP were unambiguously involved in the host parasite interaction and therefore may be useful markers in monitoring CE management and evaluating surgical stress.

KEY WORDS : cystic echinococcosis, II-6, CRP, nitrate/nitrite.
Résumé : MODIFICATIONS POST-OPÉRATOIRES DES TAUX SÉRIQUES DE CYTOKINES ET D'OXYDE NITRIQUE CHEZ DES PATIENTS PORTEURS D'UN KYSTE HYDATIQUE

L'objectif de l'étude était de mesurer les taux sériques de cytokines et de NO chez 28 patients opérés d'un kyste hydatique. Ont été mesurés avant et après intervention chirurgicale les niveaux sériques de: TNF- $\alpha$; interleukine IL- $1 \beta$; récepteurs d'IL-2R (sIL-2R), IL-6, IL-8 solubles; nitrate/nitrite; et CRP. Ces résultats ont été comparés à ceux des sérums de 28 volontaires sains. Les taux d'IL-6 étaient élevés chez tous les patients (100\%), et d'll-8 chez $11 / 28(39,3 \%)$. Des élévations des taux d'll-2R et de TNF- $\alpha$ n'ont été observés que chez certains patients, porteurs notamment $d^{\prime}$ 'un kyste centro-lobulaire du foie $15 / 28$ et $6 / 28$ respectivement). L'IL-1 $\beta$ n'était élevée chez aucun patient, à l'exception de l'un d'eux ayant développé une hydatidose secondaire sévère. Les taux de CRP et de nitrate/nitrite étaient également élevés. Une corrélation positive entre CRP et IL-6 (r = 0,74; $p<0,001)$ a été observée, confirmant le lien entre l'inflammation due au kyste et l'activation des monocytes. Tous les patients ont guéri et les taux des paramètres étudiés sont revenus à la normale, sauf chez un patient qui a présenté une récidive deux ans après l'intervention. Ces résultats suggèrent qu'il existe différents types d'immunorégulation et de réponse des cytokines au cours de l'hydatidose, pouvant être liés d'une part aux monocytes et, d'autre part, à l'activation des Th2. IL-6, NO et CRP sont sans ambiguité impliqués dans l'interaction hôte/parasite, et pourraient par conséquent être des marqueurs utiles pour le suivi des hydatidoses et l'évaluation du stress chirurgical.

MOTS CLÉS : hydatidose, IL-6, CRP, nitrate/nitrite. $\sim$ ystic echinococcosis (CE) is an important human disease that is endemic in Turkey. The most common organ involved is the liver followed by the lung. It is primarily a disease of herbivorous animals and man is infected accidentally. Clinical features of the disease are highly variable and depend on the organs involved, the size of cysts and their sites within the affected organ, the complications caused by rupture of cysts, and subsequent immunologic reactions (Torcal et al., 1996). Therapy of CE is primarily sur-

\footnotetext{
* Departments of Clinical Microbiology,

** Biochemistry, Faculty of Medicine, Inonu University, 44315 Malatya, Turkey.

Correspondence: Dr Mehmet Refik, Department of Clinical Microbiology, Faculty of Medicine, Inonu University, 44315 Malatya, Turkey.

Fax: 904223410036 - E-mail: mrtmehmet@yahoo.com
}

gical in addition to pharmacological treatment with albendazole (Silva et al., 2004).

The roles of cytokines in host immunity seem to be quite complex and may differ with the genera and species of the helminth, its size and location within the host, its metabolic products, and species of the host (Torcal et al., 1996; Dematteis et al., 2003). Moreover, conflicting cytokine responses were reported in many studies and attributed to technical and methodological points, differences in dose and type of the used stimulus or antigen and the course of the infection (Haralabidis et al., 1995; Rigano et al., 1999; Rigano et al., 2001; Mondragon-de-la-Pena et al., 2002; Fraize et al., 2004).

CE induces two very distinct $\mathrm{Th}_{1}$ and $\mathrm{Th}_{2}$ cytokine secretion patterns. They were implicated in the inactive and active stages of hydatid disease (Rigano et al., 
2004) and $\mathrm{Th}_{2}$ response is associated with susceptibility to the disease, whereas a Th1 response is related to protective immunity (Ortona et al., 2003). Th ${ }_{1}$ cells produce IL-2, IFN- $\gamma$, whereas $\mathrm{Th}_{2}$ cells express IL- 4 , IL5, IL-6 and IL-10 (Zhang et al., 2003). Most studies on CE cytokines are mainly based on in vitro experiments, i.e. determination of cytokine production following stimulation peripheral blood mononuclear cell or $\mathrm{T}$ helper cells of patients with crude and B antigens (Hernandez-Pomi et al., 1997; Fauser \& Kern, 1997; Rigano et al., 1999). These studies demonstrated an increase in the production of some cytokines such as interferongamma, IL-4, IL-5. Others demonstrated concurrent intervention of the $\mathrm{Th}_{1}$ or $\mathrm{Th}_{2}$ cells (Haralabidis et al., 1995; Rogan \& Craig, 1997; Ortona et al., 2003). The clinical status, differences between primary and recurrent infections and the severity of the clinical expression of the disease probably also affect human immunological responses to the parasite (Hernandez-Pomi et al., 1997).

Nitric oxide (NO) is an important bioregulatory molecule. It is labile (half-life $<15$ seconds) and is rapidly metabolized into nitrate and nitrite in the presence of oxygen. Although small amounts of NO are constitutively released by endothelial and neuronal nitric oxide enzymes, inducible NO, located mainly in immune cells such as macrophages, is induced and produced in considerable amounts after exposure to cytokines (Nussler et al., 1992; Lincolin et al., 1997). NO has been investigated in animal models of $\mathrm{CE}$ such as BALB/C mice (Steers et al., 2001).

C-reactive protein (CRP) is an acute phase marker most commonly used to detect inflammation in the body and monitor the activity of a range of inflammatory conditions. Infection and inflammation are the most common causes of an elevated CRP (Black et al., 2004). A positive correlation between CRP and IL- 6 was previously reported in several diseases (Kawasaki et al., 2002). However, the number of clinical studies on cytokines, NO and CRP in the serum of human CE is limited. The present study was focused on determining the effect of infection with the larval stage of $E$. granulosus on serum levels TNF- $\alpha$, IL- $1 \beta$, IL-2R, IL- 6 , IL8 , NO and CRP, monitoring their levels after surgical treatment and assessing a possible relationship of these parameters with each other.

\section{MATERIALS AND METHODS}

\section{SUBJECTS}

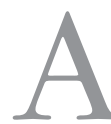

total of 28 patients with CE (nine males and 19 females), and 28 healthy controls (11 males and 117 females) were recruited for this study. Complete blood counts and differential white blood cell counts were performed on all subjects. CE was diagnosed by microscopic examination of cyst fluid for scolices or hooklets and abdominal ultrasonography, histopathological evaluation, and compatible clinical findings. A commercial kit, indirect haemagglutination test (Cellognost Echinococcosis, Behring Diagnostics Gmbh, Marburg, Germany), was used for detecting CE antibodies. Stool examination was made on both patients and controls groups to exclude intestinal parasitic infections. However, patients with other diseases were excluded. The age range of the patients with CE was 32-54 years with a mean of $44.2 \pm 20.7$ years (median $=41)$. Healthy control subjects were between 30 and 47 years old with a mean age of 38.4 years (median $=35) .28$ cysts were located in the liver, mostly in the right lobe. In 20 patients, cysts were single whereas in six subjects they were multiple. The diameters of cysts were ranged from 50 to $140 \mathrm{~mm}$. A few cases of sterile kidney cysts were excluded from this study since they were identified as simple epithelial cysts on the basis of histopathological examination, absence of scolices or hooklets and negative indirect haemagglutination test. Before surgical interventions, all patients underwent surgical operations. They were treated with albendazole at a dose of $400 \mathrm{mg}$ twice a day for one week before the operation and for one month after that to prevent a recurrence of the disease (Silva et al., 2004).

Decision was made whether control subjects were healthy according to the results of blood examination (routine biochemical and $\mathrm{CBC}$ tests) in addition to apparent healthy status with no history of current illness and pathological condition. Venous fasting blood samples were collected before initiating antiparasitic therapy and on the day of the surgery and three months after that. Blood samples were centrifuged at $2,000 \mathrm{~g}$ for 10 minutes to obtain the serum. The lipaemic or haemolysed sera were discarded and other sera were divided into three tubes for each subject and immediately stored at $-20^{\circ} \mathrm{C}$ until analysis. For each determination, a new aliquot was used since freezing and thawing of a sample more than once may partially destroy its biological actions. Permission for all procedures was taken from the local Ethical Committee and all subjects gave their informed consent to the study.

\section{CYTOKINES}

Serum levels of TNF- $\alpha$, IL-I $\beta$, sIL-2R, IL- 6 and IL- 8 were measured by means of a solid-phase two-site chemiluminescent enzyme immunometric assay with the immulite automated analyzer (DPC IMMULITE was manufactured by EURO DPC Ltd under a Quality System approved by the British Standards Institute). The results were expressed in $\mathrm{pg} / \mathrm{ml}$ except for SIL2R (U/ml). 


\section{TOTAL NITRITES}

$\mathrm{NO}$ is unstable and rapidly converted into nitrates and nitrites, it is necessary to determine both nitrite and nitrate concentrations in the samples as representatives for NO (Moshage et al., 1995). It is a common practice to use enzymatic or chemical reduction to convert all nitrates into nitrites in a sample and then measure total nitrite (Moshage et al., 1995). In the present study, serum samples were mixed with granular cadmium and shaken for two hours for chemical reduction of nitrate to nitrite, and total nitrite was then measured by spectrophotometry using the Griess reagent. All chemicals and biochemicals used for NO determination were obtained from Sigma (St.-Louis, MO, USA).

\section{C-REACTIVE PROTEIN (CRP)}

CRP levels were measured via System of automated analysers based on nephelometry (Behring Nephelometer 100 Analyzer, Behring, Germany). They were expressed as $\mathrm{mg} / \mathrm{L}$.

\section{STASTISTICAL ANALYSIS}

All data were expressed as means and standard deviations (mean $\pm \mathrm{SD}$ ). Comparison of means of variables was calculated by non parametric Mann-Whitney U test. Pearson's linear correlation test was used to assess correlation between parameters. The level of significance was set at $p<0.05$ in all analyses. All analyses were performed using the SPSS 9.0 software.

\section{RESULTS}

T The study covered 56 subjects attending Inonu University, Turgut Özal Medical Centre, Malatya, Turkey. They were 28 patients with primary active larval stage of E. granulosus, and 28 healthy controls. The ratio of males to females was 0.47 . CE occurred in all age groups; the youngest case was 32 years and the oldest was 54 years old.

Serum antibody titres were equal or higher than 1/512 by indirect haemagglutination test. Differential blood count examination showed a slight increase in the percentage of monocytes (11.3-19.1\%, normal range 0.9$6 \%)$ in majority of patients $(27 / 28,96.4 \%)$. All patients underwent surgery and they completely recovered except one woman (35 years old) in whom as many as 21 cysts were detected in the abdomen (liver, omentum, and peritoneum) two years after the operation. The mean levels of studied cytokines, CRP and nitrate/nitrite in sera of the patients with $\mathrm{CE}$ and the controls are shown in Table I. The patients had significantly elevated serum levels of CRP, IL- 6 , IL-8 and nitrite/nitrate compared to healthy controls but levels of IL- $1 \beta$ were not changed at all $(\mathrm{p}<0.05)$. IL- 6 was characteristically increased in all patients $(100 \%$; $p<$ $0.001)$. Slight increases of IL-2R, and TNF- $\alpha$ levels were found in 5/28 (17.8 \%) and 6/28 (21.4\%) respectively in those showing multiple cysts in the central area of the liver. IL-8 was increased in 11/28 (39.3\%). Studied parameters were also significantly increased in those having multiple larger cysts (Table II). A positive correlation between CRP and IL-6 $(r=0.74 ; p<0.001)$ was found confirming the link between inflammation induced in $\mathrm{CE}$ and slight monocytosis observed in $\mathrm{CBC}$

\begin{tabular}{lccc}
\hline \multicolumn{1}{c}{ Parameter } & $\begin{array}{c}\text { Controls } \\
(\mathbf{N}=\mathbf{2 8})\end{array}$ & $\begin{array}{c}\text { Patients } \\
\text { with } \mathbf{C E} \\
(\mathbf{N}=\mathbf{2 8})\end{array}$ & P value* \\
\hline TNF- $\alpha(\mathrm{pg} / \mathrm{mL})$ & $6.6 \pm 1.6$ & $9.5 \pm 1.7$ & $>0.05$ \\
IL-1 $\beta(\mathrm{pg} / \mathrm{mL})$ & $<5.0$ & $<5.0$ & $>0.05$ \\
SL-2R $(\mathrm{U} / \mathrm{mL})$ & $709.3 \pm 138.2$ & $861.7 \pm 185.1$ & $>0.05$ \\
IL-6 $(\mathrm{pg} / \mathrm{mL})$ & $6.4 \pm 1.9$ & $21.5 \pm 4.7$ & $<10^{-3}$ \\
IL-8 $(\mathrm{pg} / \mathrm{mL})$ & $26.5 \pm 9.8$ & $54.1 \pm 18.1$ & $<10^{-3}$ \\
CRP $(\mathrm{mg} / \mathrm{L})$ & $4.3 \pm 0.4$ & $13.2 \pm 6.1$ & $<10^{-3}$ \\
Total $\mathrm{nitrite}(\mu \mathrm{mol} / \mathrm{L})$ & $31.8 \pm 5.1$ & $52.5 \pm 10.8$ & $<10^{-3}$ \\
\hline
\end{tabular}

* Mann-Whitney U-test.

Table I. - Comparison serum cytokines, nitrate/nitrite and CRP levels (Mean \pm SD) in studied subjects.

\begin{tabular}{|c|c|c|c|}
\hline Parameter & $\begin{array}{l}\text { Patients with } \\
\text { single cysts } \\
(\mathbf{N}=22)\end{array}$ & $\begin{array}{c}\text { Patients } \\
\text { with multiple } \\
\text { larger cysts } \\
(N=6)\end{array}$ & P value* \\
\hline TNF- $\alpha(\mathrm{pg} / \mathrm{mL})$ & $9.1 \pm 1.4$ & $11.2 \pm 1.3$ & $<0.05$ \\
\hline $\mathrm{IL}-1 \beta(\mathrm{pg} / \mathrm{mL})$ & $<5.0$ & $<5.0$ & $>0.05$ \\
\hline sL-2R (U/mL) & $784.1 \pm 132.7$ & $1,109.9 \pm 130.2$ & $<10^{-3}$ \\
\hline IL-6 (pg/mL) & $20.7 \pm 4.4$ & $24.5 \pm 4.6$ & $>0.05$ \\
\hline IL-8 (pg/mL) & $50.5 \pm 18.2$ & $66.7 \pm 11.2$ & $<10^{-2}$ \\
\hline $\mathrm{CRP}(\mathrm{mg} / \mathrm{L})$ & $10.9 \pm 4.2$ & $21.8 \pm 2.5$ & $<10^{-3}$ \\
\hline Total nitrite $(\mu \mathrm{mol} / \mathrm{L})$ & $48.5 \pm 8.4$ & $66.9 \pm 4.4$ & $<10^{-3}$ \\
\hline
\end{tabular}

* Mann-Whitney U-test.

Table II. - Comparison serum cytokines, nitrate/nitrite and CRP levels (Mean $\pm \mathrm{SD}$ ) according to number of cysts.

\begin{tabular}{lccc}
\hline & $\begin{array}{c}\text { First day } \\
\text { after } \\
\text { operation } \\
\text { Parameter }\end{array}$ & $\begin{array}{c}\text { Three months } \\
\text { after } \\
\text { operation }\end{array}$ & \\
\hline TNF- $\alpha(\mathrm{pg} / \mathrm{mL})$ & $38.5 \pm 5.4$ & $9.9 \pm 0.7$ & $<10^{-3}$ \\
IL-1 $\beta(\mathrm{pg} / \mathrm{mL})$ & $32.1 \pm 6.2$ & $<5.0$ & $<10^{-3}$ \\
SL-2R $(\mathrm{U} / \mathrm{mL})$ & $1,248.7 \pm 327.9$ & $681.3 \pm 98.4$ & $<10^{-3}$ \\
IL-6 $(\mathrm{pg} / \mathrm{mL})$ & $63.1 \pm 12.5$ & $9.2 \pm 1.6$ & $<10^{-3}$ \\
IL-8 $(\mathrm{pg} / \mathrm{mL})$ & $102.6 \pm 26.8$ & $25.9 \pm 6.1$ & $<10^{-3}$ \\
CRP $(\mathrm{mg} / \mathrm{L})$ & $33.4 \pm 10.7$ & $4.4 \pm 0.5$ & $<10^{-3}$ \\
Total $\mathrm{nitrite}(\mu \mathrm{mol} / \mathrm{L})$ & $81.2 \pm 11.4$ & $34.9 \pm 6.6$ & $<10^{-3}$ \\
\hline
\end{tabular}

* Mann-Whitney U-test.

Table III. - Serum cytokines, nitrate/nitrite and CRP levels (Mean \pm SD) at different periods after surgical operation. 
results. No significant correlation existed among other parameters.

On the first day after operation, the mean levels of all studied cytokines showed significant elevations. After surgical removal of the cysts, elevated serum parameters returned to normal levels three months after operation (Table III). Conversely, a transient decrease in studied mediators was observed in the 35 years old woman patient who had 21 secondary cysts in the abdomen (liver, omentum and peritoneum) two years after surgery and had significantly increased serum TNF- $\alpha$, IL-I $\beta$, IL-6, IL-8, CRP and total nitrites concentrations.

\section{DISCUSSION}

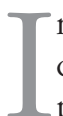
n assessing the results of this study, IL-6, a type 2 cytokine, was elevated in the vast majority of 1 patients with CE $(96.7 \%)$. The major role of this cytokine is to induce differentiation of $\mathrm{B}$ cells into plasma cells. This clearly indicates activation of $\mathrm{Th}_{2}$ cells and monocytes and it is implicated in host parasite interaction by contributing to the development of humoral response (Van Snick, 1990). Other cytokines such as TNF- $\alpha$, sIL-2R were elevated in a minority of patients and/or no change in IL- $1 \beta$ expression could be detected. sIL-2R elevation in minority of cases may be due to a weak activation of $\mathrm{Th}_{1}$ cells while a decrease in TNF- $\alpha$ percentage may be contributed to IL- 6 which decreases the level of TNF- $\alpha$ (Schindler et al., 1990; Cohen \& Cohen, 1996). An inflammatory chemokine such as IL-8, mostly expressed by monocytes, was increased in nearly one third of patients. Slight blood monocytosis was observed in most of our patients. CE is in fact a chronic disease and the presence of cysts for several months or years may have a major role in modulating cytokine production via prolonged stimulation by cyst fluid antigen. On comparing cytokine profiles of the present study with those of alveolar echinococcosis (Wellinghausen et al., 1999; Shi et al., 2004), compable cytokine profiles were found in cystic versus alveolar echinococcosis, the parasitic agents being very similar but the clinical course very different.

NO was not investigated in human CE but the interaction between hydatid cyst and $\mathrm{NO}$ was investigated in mice (Steers et al., 2001). NO was produced by macrophages from mice infected with $E$. multilocularis that resulted in immunosuppression and prolonged larval growth and survival (Dai \& Gottstein, 1999). In this study, there was a significant increase in nitrate/ nitrite levels which may be attributed to elevated levels of cytokines production (Nussler et al., 1992; Lincolin et al., 1997).

CRP is recognized as a traditional inflammation or infection marker. According to literature review, the role of
CRP has not yet been investigated in CE. It was significantly increased in our CE patients and correlated significantly to IL-6 $(r=0.74 ; p<0.001)$. Elevated serum CRP levels may be due to an increased production of IL- 6 as a result of the activation of monocytes (Heinrich et al., 1990). Our results support the role of interleukin- 6 in the induction of CRP synthesis (Castell et al., 1989). It can be a useful marker in the diagnosis and activity of $\mathrm{CE}$ and in monitoring the efficiency of the treatment since it can be measured in a less sophisticated and expensive way.

Little is known about the effect of surgical intervention on serum mediators. Surgical damage induces cytokine response to an extent depending on the type of operation and severity of surgical trauma (Cruickshank et al., 1990; Yamauchi et al., 1998). The greater the surgical trauma, the greater the response of serum interleukin-6 is. In the present work, there was a significantly sharp increase in studied cytokines and nitrate/ nitrite levels immediately after the operation in spite of the absence of postoperative complication such as infection. The most probable reason was surgical stress and subsequent activation of immune response.

Albendazole was routinely used in postoperative therapy in patients with CE. Nevertheless, in the present study many secondary cysts recurred in the abdomen of one female patient at in interval of two years after the first operation. This is most probably the result of complication of the first surgical intervention. The patient had significantly increased serum TNF- $\alpha$, IL-I $\beta$, IL-6, IL-8, CRP and total nitrites concentrations. This finding could mean an enhanced immunological response when cysts are multiple and secondary due to a probably increased cyst antigen stimulation and in turn more activation of immune cells.

In conclusion, CE causes activation of monocytes and $\mathrm{Th}_{2}$ cells via increased production of IL-6 and monocytosis and in turn increasing CRP and NO production. Such activation was enhanced during surgery since surgical stress can trigger the production of inflammatory cytokines and NO as well. Three months after the surgery, all parameters which may have a role in $\mathrm{CE}$ pathophysiology returned to normal levels suggesting that they may be helpful in following up the effectiveness of surgical treatment.

\section{REFERENCES}

Black S., Kushner I. \& Samols D. C-reactive protein. Journal of Biological Chemistry, 2004, 279, 48487-48490.

Castell J.V., Gomez-Lechon M.J., David M., Andus T., GeiGer T., Trullengue R., Fabra R. \& Heinrich P.C. Interleukin6 is the major regulator of acute phase protein synthesis in adult human hepatocytes. FEBS Letters, 1989, 242, 237239. 
Cohen M.C. \& Cohen S. Cytokine function: A study in biologic diversity. American Journal of Clinical Pathology, 1996, 105, 589-598.

Cruickshank A.M., Fraser W.D., Burns H.J., Van Damme J. \& SHENkIN A. Response of serum interleukin-6 in patients undergoing elective surgery of varying severity. Clinical Science, 1990, 79, 161-165.

DAI W.J. \& GotTstein B. Nitric oxide-mediated immunosuppression following murine Echinococcus multilocularis infection. Immunology, 1999, 97, 107-116.

Dematteis S., Rottenberg M. \& Baz A. Cytokine response and outcome of infection depends on the infective dose of parasites in experimental infection by Echinococcus granulosus. Parasite Immunology, 2003, 25, 189-197.

FAuser S. \& Kern P. T-lymphocyte cytokine mRNA expression in cystic echinococcosis. Acta Tropica, 1997, 64, 3551.

Fraize M., Sarciron M.E, Saboulard D., Azzouz S., Debard A.L., Bosquet G. \& Petavy A.F. An in vitro model to evaluate the cytokine response in Echinococcus infections. Parasite Research, 2004, 92, 506-512.

Haralabidis S., Karagouni E., Frydas S., \& Dotsika E. Immunoglobulin and cytokine profile in murine secondary hydatidosis. Parasite Immunology, 1995, 17, 625-630.

Heinrich P.C., Castell J.V. \& Andus T. Interleukin-6 and the acute phase response. Biochemical Journal, 1990, 265, 621-636.

Hernandez-Pomi A., Borras-Salvador R. \& Mir-Gisbert A. Analysis of cytokine and specific antibody profiles in hydatid patients with primary infection and relapse of disease. Parasite Immunology, 1997, 19, 553-561.

Kawasaki Y., Hosoya M., Katayose M. \& Suzuki H. Correlation between serum interleukin- 6 and C-reactive protein concentrations in patients with adenoviral respiratory infection. Pediatric Infectious Disease Journal, 2002, 21, 370-374

Lincolin L., Hoyle H.V. \& Burnstock G. Nitric oxide in health and disease. Cambridge University Press, Cambridge, 1997, 12-26, 105-113.

Mondragon-De-La-Pena C., Ramos-Solis S., Barbosa-Cisneros O., Rodriguez-Padilla C., Tavizon-Garcia P. \& HerreraEsPaRZA R. Echinococcus granulosus down regulates the hepatic expression of inflammatory cytokines IL-6 and TNF- $\alpha$ in BALB/c mice. Parasite, 2002, 9, 351-356.

Moshage H., Kok B., Huizenga J.R. \& Jansen P.L. Nitrite and nitrate determinations in plasma: a critical evaluation. Clinical Chemistry, 1995, 41, 892-896.

Nussler A.K., Di Silvio M., Billiar T.R., Hoffman R.A., Geller D.A., Selby R., Madariaga J. \& Simmons R.L. Stimulation of the nitric oxide synthase pathway in human hepatocytes by cytokines and endotoxin. Journal of Experimental Medicine, 1992, 176, 261-264.

Ortona E., Rigano R., Buttari B., Delunardo F., Ioppolo S., Margutti P., Profumo E., Teggi A., Vaccari S., \& SiracuSANO A. An update on immunodiagnosis of cystic echinococcosis. Acta Tropica, 2003, 85, 165-171.

Rigano R., Profumo E., Buttari B., Teggi A. \& Siracusano A. Cytokine gene expression in peripheral blood mononu- clear cells (PBMC) from patients with pharmacologically treated cystic echinococcosis. Clinical and Experimental Immunology, 1999, 118, 95-101.

Rigano R., Profumo E., Bruschi F., Carulli G., Azzara A., Ioppolo S., Buttari B., Ortona E., Margutti P., Teggi A. \& Siracusano A. Modulation of human immune response by Echinococcus granulosus antigen B and its possible role in evading host defenses. Infection and Immunity, 2001, 69, 288-296

Rigano R., Buttari B., De Falco E., Profumo E., Ortona E., Margutti P., Scotta C., Teggi A. \& Siracusano A. Echinococcus granulosus-specific T-cell lines derived from patients at various clinical stages of cystic echinococcosis. Parasite Immunology, 2004, 26, 45-52.

Rogan M.T. \& CRAig P.S. Immunology of Ecchinococcus granulosus infections. Acta Tropica, 1997, 67, 7-17.

Schindler L., Mancilla J., Endres S., Ghorbani R., Clark S.C. \& Dinarello C.A. Correlations and interactions in the production of interleukin-6 (IL-6), IL-1, and tumor necrosis factor (TNF) in human blood mononuclear cells: IL-6 suppresses IL-1 and TNF. Blood, 1990, 75, 40-47.

Shi D.Z., Li F.R., Bartholomot B., Vuitton D.A. \& Craig P.S. Serum sIL-2R, TNF- $\alpha$ and IFN- $\gamma$ in alveolar echinococcosis. World Journal of Gastroenterology, 2004, 10, 3674-3676.

Silva M.A., Mirza D.F., Bramhall S.R., Mayer A.D., McmasTER P. \& Buckels J.A. Treatment of hydatid disease of the liver. Digestive Surgery, 2004, 21, 227-234.

Steers N.J., Rogan M.T. \& Heath S. In vitro susceptibility of hydatid cysts of Echinococcus granulosus to nitric oxide and the effect of the laminated layer on nitric oxide production. Parasite Immunology, 2001, 23, 411-417.

Torcal J., Navrrozorraquino M., Lozano R., Larrad L., Salins J.C., Roman J. \& Pastor J. Immune response and in vivo production of cytokines in patients with liver hydatidosis. Clinical and Experimental Immunology, 1996, 106, 317322.

VAN SNICK J. Interleukin-6: an overview. Annual Review Immunology, 1990, 8, 253-278.

Wellinghausen N., Gebert P. \& Kern P. Interleukin IL-4, IL10 and IL-12 profile in serum of patients with alveolar echinococcosis. Acta Tropica, 1999, 73, 165-174.

Yamauchi H., Kobayashi E., Yoshida T., Kiyozaki H., Hozumi Y., Kohiyama R., Suminaga Y., Sakurabayashi I., Fujimura A. \& MiYata M. Changes in immune-endocrine response after surgery. Cytokine, 1998, 10, 549-554.

Zhang W., Li J. \& Mcmanus D.P. Concepts in immunology and diagnosis of hydatid disease. Clinical Microbiology Reviews, 2003, 16, 18-36.

Reçu le 22 octobre 2004 Accepté le $1^{\text {er }}$ mars 2005 